\title{
Feasibility Study Stage of Highway Engineering in Mountainous Area Compilation of Estimation Quantity Table of Temporary Works
}

\author{
Wei Zhang*, Ru Mou, PengYang \\ Broadvision Engineering Consultants Co. Ltd., Kunming, Yunnan, China \\ *Corresponding Author.
}

\begin{abstract}
Reasonable estimation of the project quantity in the feasibility study stage of mountain highway project is one of the basis for the preparation of investment estimation. Combined with the practical work for many years, the content and method of the temporary project, safety measures and other engineering quantity table in feasibility study stage of the highway project in Chongqiu District of mountain are introduced. Taking the calculation of the temporary project of Ningxiang expressway as an example, the basic method of calculation of the maintenance and restoration of the construction access road, the bridge and the original road in mountainous area is analyzed. The author concludes that the influence of geological conditions, topography and original traffic facilities should be considered comprehensively when preparing the temporary engineering quantity table.
\end{abstract}

Keywords: Temporary works, temporary safety measures, other works, construction access, original road maintenance and restoration

\section{Introduction}

The feasibility study of highway construction project requires the preparation of investment estimation, which is an important part of the feasibility study report [1]. It is one of the bases of demonstration of technical feasibility, economic rationality and implementation possibility. It is an important basis for decision-making of construction projects. It is an important work to reasonably determine and control the project investment in the feasibility study stage [2].

The preparation of investment estimation is to fully understand the construction conditions of the project site, master all basic data, correctly quote indexes, charging standards, labor unit price, material and equipment price according to the design documents of the project, The work is carried out according to the current implementation of the Method for the Preparation of Investment Estimation of Highway Infrastructure Projects and Highway Engineering Estimation Index and the provisions in line with the current relevant national and industrial standards [4].

The reasonable estimation of the project quantity in the feasibility study stage is the key work of the feasibility study and the important basic data for the preparation of the investment estimation. The project feasibility study project quantity includes: estimation of temporary works, subgrade works, pavement works, bridge culvert works, tunnel works, crossing works, facilities along the line, greening and environmental protection works, other projects, land use scale and demolition, etc [5].

Temporary engineering is one of the basic data of the project quantity estimation in the feasibility study stage. Temporary works are not the only service objects, but only participate in the permanent project construction [6-10]. After completion, the project needs to be restored to its original state. Temporary project is an integral part of construction organization design. The construction of the project cannot be separated from temporary works, including production and living facilities, temporary construction site, temporary roads and temporary power and

ISSN: 0010-8189

(C) CONVERTER 2021

www.converter-magazine.info 
telecommunication lines. Temporary safety measures, temporary small facilities, etc.

The estimation of temporary project quantity in the feasibility study stage is reflected by the preparation of the provisional project quantity estimation table. According to the relevant provisions of highway engineering implemented at the current stage, the standardization of the project quantity estimation table in the feasibility study stage is promoted, and the standardization has the benefit of raising the efficiency of the cost document preparation. The standardization and standardization of cost documents are conducive to the whole process control of cost documents.

\section{Preparation of Estimation Table for Temporary Works}

2.1Different pricing requirements for temporary works in preparation method for investment estimation of highway capital construction project

The cost of temporary works and temporary facilities is easy to be repeatedly priced or omitted. Therefore, it is necessary to compile the quantity of temporary works according to the compilation methods of different stages and the contents required by indicators and quotas.

Temporary works and temporary facilities are priced separately in the investment estimation of project feasibility study stage. The construction site construction cost in item 10 of the construction and installation engineering cost in the investment estimation project includesas table 1.

Table 1Construction site construction cost

\begin{tabular}{|c|c|c|}
\hline No. & Item & Cost breakdown \\
\hline 1 & $\begin{array}{c}\text { Production and living } \\
\text { houses }\end{array}$ & $\begin{array}{c}\text { The office and living houses, public houses and production houses required by } \\
\text { the Contractor's residence, construction of site laboratory, centralized } \\
\text { processing of reinforcement, centralized mixing of mixture, construction of } \\
\text { centralized prefabrication, etc }\end{array}$ \\
\hline 2 & $\begin{array}{c}\text { Site and supporting } \\
\text { expenses }\end{array}$ & $\begin{array}{c}\text { Site leveling, site hardening, drainage, greening, signs, sewage treatment } \\
\text { facilities, wall isolation facilities, etc }\end{array}$ \\
\hline 3 & $\begin{array}{c}\text { Temporary facilities in } \\
\text { the site }\end{array}$ & $\begin{array}{c}\text { The expenses for temporary work roads, temporary bridges, pedestrian roads, } \\
\text { water pipes and points for temporary water and electricity in the plant area, as } \\
\text { well as the expenses for the erection, lease, maintenance, demolition and } \\
\text { cleaning of temporary structures and other small temporary facilities. }\end{array}$ \\
\hline 4 & $\begin{array}{c}\text { Site laboratory related } \\
\text { costs }\end{array}$ & $\begin{array}{c}\text { Depreciation, maintenance or rental expenses of equipment and instruments in } \\
\text { the field laboratory. }\end{array}$ \\
\hline 5 & $\begin{array}{c}\text { Cost of environmental } \\
\text { protection measures in } \\
\text { construction section }\end{array}$ & $\begin{array}{c}\text { The cost of covering dust-proof net, sprinkling water or spraying dust agent on } \\
\text { construction road and construction site, covering and washing transport } \\
\text { vehicles, setting fences in environmentally sensitive areas, setting dust-proof } \\
\text { signs, environmental monitoring and testing, etc. }\end{array}$ \\
\hline 6 & $\begin{array}{c}\text { Cost of civilized } \\
\text { construction and healthy } \\
\text { life of workers }\end{array}$ & \multicolumn{2}{|c|}{} \\
\hline
\end{tabular}

It has been made clear in the estimation method that temporary works do not include access roads, construction roads, temporary bridges, temporary wharves, track laying, erection of temporary power lines, etc. Therefore, the above quantity shall be compiled in combination with the requirements of Highway Engineering Estimation Index.

2.2Contents of temporary works in highway engineering estimation index

The preparation of the quantity table of temporary works in the feasibility study stage of the project is mainly based on the contents and measurement rules of the temporary works in the highway engineering estimation index. First of all, we need to be familiar with the contents and measurement rules of the temporary works in the highway engineering estimation index.

ISSN: 0010-8189

www.converter-magazine.info 
According to estimation index of highway engineering, temporary works include temporary road, temporary bridge, temporary wharf and other temporary works. The index does not include the demolition of old buildings, structures, three reconstruction projects (river, ditch and road).

\subsubsection{Temporary roads and bridges}

Temporary roads and bridges are specially used for automobile transportation of building materials and living materials; Access roads and bridges for large construction machinery.

Due to different construction conditions and main works, the situation and scale of temporary roads and bridges are quite different. The classification, grade and pricing requirements of different stages in the early stage of the project are also different. For example, the decision-making stage, that is, the stage of project feasibility study, is generally referred to as the construction road, and the simple road and complex road are subdivided for pricing. The design stage is the stage of preliminary design or construction drawing, and the quantity of construction access road and access road is calculated in detail according to different levels.

The temporary access indicators in the highway engineering estimation index include simple and complex roads. The index has been clear that complex access road refers to the highway or independent special long tunnel construction in the mountainous and hilly area, and the rest is simple access road. Temporary access roads are prepared according to the terrain conditions and different subgrade width.The simple access road in the index includes all works of subgrade, pavement, maintenance, etc. Complex road includes subgrade, pavement, bridge and culvert, drainage protection and other work. The temporary road in the index is calculated according to the length of the road to be built.

The index base price of simple access road and complex access road is different from that of similar terrain conditions and subgrade width. For example, the index base price of simple access road with subgrade width of $4.5 \mathrm{~m}$ in heavy hilly area is 106551 yuan / $\mathrm{km} ; 779050$ yuan / $\mathrm{km}$.

When compiling the quantity table of temporary access roads, the estimated quantity of simple access roads and complex access roads should be reasonably determined according to the project scale.

\subsubsection{Temporary bridge project content in highway engineering estimation index}

The index is calculated according to the number of temporary wharves. Due to the turbulent and seasonal river conditions in mountainous areas, the temporary wharf engineering facilities are not used in the feasibility study stage of highway engineering in mountainous areas.

\subsubsection{Other contents of temporary works in highway engineering estimation index}

Other temporary projects include temporary power lines, other temporary sporadic projects, and all the work before handover. Other temporary works in the indicators are classified according to different highway grades (highway, grade 1, grade 2, grade 3 and grade 4) and terrain conditions (plain hilly area and mountainous heavy hilly area), and calculated according to the length of construction project route.

Other temporary works are generally not reflected in the quantity table, and the cost staff shall price according to the length of the route.

\subsection{Preparation of quantity table of temporary road and bridge}

According to the work content and description of temporary roads and bridges in the above indicators, the quantities of temporary roads and bridges in the feasibility study stage can be prepared by referring to the following table.

The construction access roads in mountainous and hilly areas are generally the horizontal construction access roads built from the existing roads to the main structures of the highway line, such as the mixing site, construction camp and site, and the vertical construction access roads along the route for the transportation of building materials. In the feasibility study stage of the project, the number of construction roads is calculated according to the designed topographic map, satellite map, on-site investigation of existing road operation and road grade, and the engineering facilities such as tunnels, super large bridges, bridges, main excavation and filling sections. The following takes the feasibility study of Ningxiang expressway project as an example to illustrate the establishment of the number of temporary roads and bridges.

Take the number of temporary roads and bridges on Ningxiang Expressway as an example. For K24 + 215-k44 + 220 section in the above table, the length of access road is $23.4 \mathrm{~km}$, including $13.9 \mathrm{~km}$ of complex access road and

ISSN: 0010-8189

(C) CONVERTER 2021

www.converter-magazine.info 
$9.5 \mathrm{~km}$ of simple access road; There are 9 temporary bridges of $90 \mathrm{~m}$. The specific quantity is as Figue 1 and Figure 2.

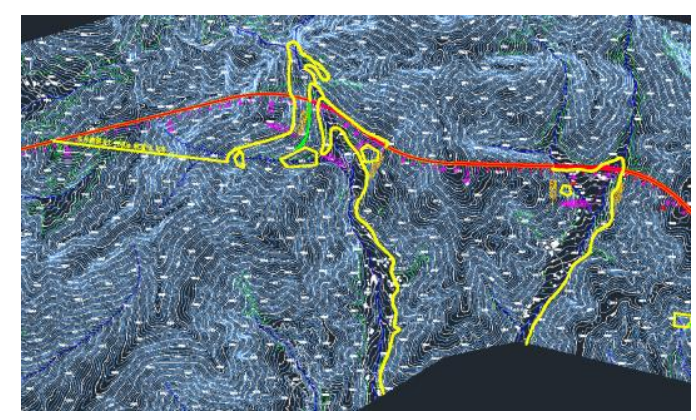

Fig 1:Schematic diagram of construction road (1)

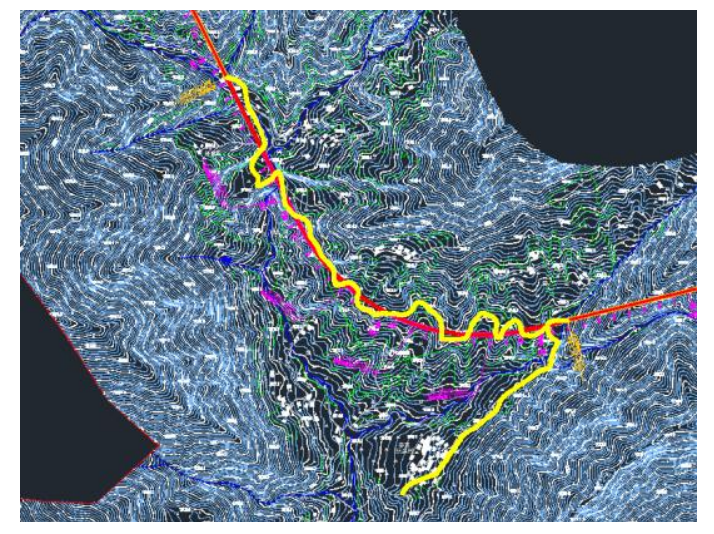

Fig.2:Schematic diagram of construction road (2)

$\mathrm{K} 24+215-\mathrm{k} 44+220$ section, there are 6 extra long tunnels and 8 large bridges, as shown in the above table and figure (in the figure, yellow is complex access road and green is simple access road). Considering the height difference between the existing road and the construction site, the length of the transverse construction road is calculated according to the average longitudinal slope of $5.5 \%$. In the principle of longitudinal construction access, the minimum engineering scale shall be considered to meet the calculation length of the maximum longitudinal slope, and the number of simple access roads for Subgrade and tunnel transverse transportation of abandoned earthwork shall be considered in the construction access. Finally, the total number of construction roads in this section is $23.4 \mathrm{~km}$.

The simple road is calculated according to the subgrade width of $4.5 \mathrm{~m}$, and the total length of the simple road is $9.5 \mathrm{~km}$, of which the longitudinal simple road is $5.5 \mathrm{~km}$ and the transverse simple road is $4.0 \mathrm{~km}$. Due to the steep cross slope of the project area, the complex access road is located in the high altitude area (most of the road sections are above $2000 \mathrm{~m}$ above sea level), Combined with the rural road network along the line, the subgrade width is calculated as $6.5 \mathrm{~m}$ for double car road, and the length of complex access road is $13.9 \mathrm{~km}$, including $0.9 \mathrm{~km}$ for longitudinal complex access road and $13.0 \mathrm{~km}$ for transverse simple access road.

The temporary construction bridge shall be set according to the topographic map. In principle, the temporary construction bridge shall be set for the rivers with long flowing water. The number of temporary piers in water shall be considered for the rivers with river surface more than $20 \mathrm{~m}$. The construction access road of K24+215-k44 +220 section involves nine ditches with long running water. In order to ensure the traffic throughout the year, nine temporary bridges with a total length of $90 \mathrm{~m}$ are set up. No rivers are involved and no temporary piers are calculated.

2.4 Preparation of quantity table for maintenance and restoration of original roads

With the coverage of rural road network, some rural roads need to be used as transportation channels in

ISSN: 0010-8189

(C) CONVERTER 2021

www.converter-magazine.info 
mountainous areas. However, most of the rural roads in mountainous areas are designed according to the base width of 4.5 meters for single vehicle roads, and generally the pavement is designed according to light traffic volume. The slope protection is weak. During the construction period, a large number of construction vehicles are transported in a centralized way, which causes serious damage to the pavement and drainage facilities. It is necessary to add engineering measures to the drainage system and slope protection of the original road, add a wrong lane, and carry out routine maintenance and warranty on the pavement. After the completion of the construction, the original road surface and part of the base need to be re paved, and handed over to the local government after meeting the relevant standards.

At present, there is no direct estimation index for the maintenance and repair of the original road, so it is necessary to estimate the detailed quantities of Subgrade Earthwork, drainage and protection, pavement, etc., and apply the corresponding index and budget quota when pricing.

The estimation table of the maintenance and restoration quantity of the original roads on runing Xiangtan line is as follows. In $\mathrm{K} 24+215-\mathrm{k} 44+220$ section, the original road is $4.0 \mathrm{~km}$, the width of subgrade is $4.5 \mathrm{~m}$, and the pavement surface is cement concrete pavement. It is necessary to repair the subgrade in some sections, add a passing lane, and estimate the amount of Subgrade Earthwork of 12000m3; Repair drainage facilities $160 \mathrm{~m} 3$; Routine repair and maintenance pavement (estimated by $35 \%$ of pavement quantity) $6300 \mathrm{~m}^{2}$; In the later stage of implementation, the original road surface is restored with an area of $18000 \mathrm{~m}^{2}$.

2.5 Preparation of quantity table of Baotong temporary safety measures and Baotong temporary engineering measures

In addition to the above temporary works, the existing road expansion and reconstruction, the junction with highgrade highway (such as ramp in hub interchange area), the intersection with the highway along the line, and the villages and towns on both sides of the line, etc. in order to ensure the traffic of the existing road, the safety of the villages under the road, the safe operation under the bridge and the normal construction, it is necessary to set up the necessary temporary measures to ensure the traffic Baotong road temporary engineering measures, other temporary safety measures, etc.

2.5.1 Preparation of quantity table of Baotong temporary safety measures

When the construction project intersects with the existing road and sets up hub interchange and general interchange, it needs to connect with the original road, or the main line crosses the existing road, along the existing road reconstruction and expansion project, it needs to maintain traffic while construction, it needs to set up necessary temporary safety measures to ensure the operation safety of the existing road.

Temporary safety measures mainly include temporary marking, color steel tile enclosure, anti-collision bucket, construction warning light, deceleration belt, temporary signs, anti-falling net under bridge, etc. At present, there is no direct estimation index for the number of temporary safety measures, which needs to be prepared according to the requirements of budget estimate and budget, as shown in the table below:

For AK1 + 400-AK2 + 600 section in the above table, the intersection of cross junction interchange and Yuchu Expressway shall be set, and at the junction of interchange ramp and Yuchu expressway, the marking arrow, lane change and other markings of $1200 \mathrm{M} 2$ shall be set at Yuchu expressway; $8800 \mathrm{~m}^{2}$ color steel tiles are set on both sides for enclosure, and 800 anti-collision buckets are set at the same time. In order to ensure the safety of driving at night, 160 construction warning and warning lights are set, $160 \mathrm{~m}$ deceleration belt is set at both ends of the construction area, and 8 single column warning and indicator signs are set. At the same time, the main line and some ramps are equipped with bridges over Yuchu expressway. In order to ensure the operation safety under the bridge in the construction section, it is necessary to set $3200 \mathrm{~m}^{2}$ anti falling net under the bridge.

In addition to marking and temporary signs, the above quantities can be priced by budgetary estimate quota, and other expenses can be priced by the method of quantity multiplying unit price through comprehensive unit price of market research. It is also necessary to calculate the cost of dismantling the above measures when preparing the estimated cost.

2.5.2 Preparation of quantity table of temporary engineering measures for Baotong Road

The access control of high-grade highway route will occupy part of the original road or cross with the original road, and some of the original roads will be relocated, especially when the road along the line crosses the main line and

ISSN: 0010-8189

(C) CONVERTER 2021

www.converter-magazine.info 
bridges are set up, temporary traffic protection engineering measures shall be taken for the original road, and the quantity of excavated stonework shall be estimated for the traffic protection engineering. The quantities of drainage works, protection works, pavement works, etc. shall be prepared according to the requirements of the estimation indexes. The estimation of the quantities of works can be made according to the empirical estimation method. Besides the above expenses, the cost of demolishing the temporary Baotong road works shall also be calculated.

For AK $9+900-A K 10+218$ section in the above table, it is necessary to set up traffic protection engineering measures for the original road with a length of $200 \mathrm{~m}$ and a width of $7.5 \mathrm{~m}$, with a total of $2800 \mathrm{~m}^{3}$ of Subgrade Earthwork, $216 \mathrm{~m}^{3}$ of drainage engineering measures and $1200 \mathrm{~m}^{2}$ of pavement surface.

\subsubsection{Other temporary safety measures}

There are roads, villages and towns along the mountain highway. In order to prevent the safety of villages and roads on the opposite side such as rockfall during construction, it is necessary to set up temporary passive anti rockfall net.

Passive anti falling net is measured according to the estimation index measurement rules, and only the area of passive anti falling net is calculated for the estimated quantity. The index has integrated all the processes of foundation concrete pouring, steel pipe column production, installation, hanging net and so on.

In $\mathrm{K} 11+000-\mathrm{K} 20+500$ section in the above table, there are two villages distributed under the road. Bridges and subgrade are set to pass through the road. In order to ensure the safety of villages during construction, each village is estimated to be $50 \mathrm{~m}$ long and $2.0 \mathrm{~m}$ high, with an area of $200 \mathrm{~m}^{2}$.

\section{Conclusion}

At the present stage, the empirical estimation method is mainly used to prepare the bill of quantities of temporary works, Baotong temporary safety measures and other works in the feasibility study stage. It has been applied to the feasibility study of most expressways in mountainous and hilly areas of Yunnan Province, such as Chujing expressway, Ningxiang expressway, Eshihong expressway and so on, and the effect is remarkable. With the improvement of scientific and technological means; Application program promotion; The accuracy of basic data collection is improved, and the compilation and estimation methods of temporary project quantity, Baotong temporary safety measures and other project quantity in the feasibility study stage are continuously improved, which can greatly improve the efficiency and quality of engineering feasibility study compilation.

\section{References}

[1] P. Strauss-Raats, "Temporary safety. Regulating working conditions in temporary agency work,"Safety Science, vol.112, no.1, pp.212-222, 2019.

[2] C.T. Liu, C. Wu, C. W. Hu, "Managing Temporary Workers by Defining Temporary Work Agency Service Quality,"Human Resource Management, vol.49, no.4, pp.619-646, 2010.

[3] I. Rybnikova, "Employee voice and silence in temporary agency work," German Journal of Human Resource Management-Zeitschrift Fur Personalforschung, vol.30, no.3-4, pp.287-309, 2010.

[4] M. Kauhanen, J. Natti, "Involuntary Temporary and Part-Time Work, Job Quality and Well-Being at Work,"Social Indicators Research, vol.120, no.3, pp.783-799, 2015.

[5] L. Grau-Lopez, C. Daigre, A. Granell,"Risk factors for temporary work disability,"Actas Espanolas De Psiquiatria, vol.44, no.4, pp.119-124, 2016.

[6] J. Jeunet, M. B.Orm, “Optimizing temporary work and overtime in the Time Cost Quality Trade-off Problem," European Journal of Operational Research, vol.284, no.2, pp.19-24,2020.

[7] A. Kazaz, S. Ulubeyli, B. Er, et al.,"Construction Materials-based Methodology for Time-Cost-quality Trade-off Problems,” Procedia Engineering, no.164, pp.35-41, 2016.

[8] H. Chen,"Study on the Training Pattern of Tourism Management Teachers on Temporary Work Off- 
campus in Applied Baccalaureate Universities Taking Zhaoqing University as an Example,"Proceedings of the 3rd International Conference on Culture, Education and Economic Development of Modern Society (ICCESE 2019), 2019.

[9] D.Redfern, "When is a temporary workplace not a temporary workplace for tax purposes?" Accountancy, no.4, pp.1-15, 2019.

[10] Z.Yang, Y. Liu, L. I. Guochang, et al.,"Structural Development and Finite Element Analysis of a New Prefabricated Temporary Work Shed," Journal of Shenyang Jianzhu University(Natural Science), 2019. 